\title{
AMH and AMHR2 Involvement in Congenital Disorders of Sex Development
}

\author{
Franco G. Brunello a, b Rodolfo A. Rey ${ }^{a, c}$ \\ aCentro de Investigaciones Endocrinológicas "Dr. César Bergadá" (CEDIE), CONICET - FEI - División de Endocrinología, \\ Hospital de Niños Ricardo Gutiérrez, Buenos Aires, Argentina; ' Instituto de Química Biológica de la Facultad de Ciencias \\ Exactas y Naturales (IQUIBICEN), CONICET, Buenos Aires, Argentina; 'Departamento de Histología, Embriología, Biología \\ Celular y Genética, Facultad de Medicina, Universidad de Buenos Aires, Buenos Aires, Argentina
}

\author{
Keywords \\ Disorders of sex development · Fallopian tubes . \\ Hypogonadotropic hypogonadism · Ovary · Persistent \\ Müllerian duct syndrome · Sertoli cell · Testis · Uterus
}

techniques, AMH and AMHR2 expression has also been detected in other tissues, and massive sequencing technologies have unveiled variants in $A M H$ and $A M H R 2$ genes in hitherto unsuspected conditions.

\begin{abstract}
Anti-müllerian hormone (AMH) is 1 of the 2 testicular hormones involved in male development of the genitalia during fetal life. When the testes differentiate, AMH is secreted by Sertoli cells and binds to its specific receptor type II (AMHR2) on the müllerian ducts, inducing their regression. In the female fetus, the lack of AMH allows the müllerian ducts to form the fallopian tubes, the uterus, and the upper part of the vagina. The human $A M H$ gene maps to $19 p 13.3$ and consists of 5 exons and 4 introns spanning 2,764 bp. The AMHR2 gene maps to $12 q 13.13$, consists of 11 exons, and is $7,817 \mathrm{bp}$ long. Defects in the AMH pathway are the underlying etiology of a subgroup of disorders of sex development (DSD) in $46, X Y$ patients. The condition is known as the persistent müllerian duct syndrome (PMDS), characterized by the existence of a uterus and fallopian tubes in a boy with normally virilized external genitalia. Approximately 200 cases of patients with PMDS have been reported to date with clinical, biochemical, and molecular genetic characterization. An updated review is provided in this paper. With highly sensitive
\end{abstract}

\section{Introduction}

Anti-müllerian hormone (AMH), formerly also called müllerian inhibiting substance (MIS) or factor (MIF), is 1 of the 2 testicular hormones that drive the sexually dimorphic process of genital differentiation during fetal life (Fig. 1). Although chromosomal sex, 46,XX or 46,XY in mammals, becomes fixed at fertilization and depends on the sex chromosome present in the spermatozoon, a period elapses before the first signs of sex differentiation are evident in the developing embryo. For instance in humans, during the first 6 weeks of gestation, the gonads and the primordia of the internal and external genitalia are identical in 46,XX and 46,XY embryos. When the testes differentiate in the 7th week, Sertoli cells start producing $\mathrm{AMH}$, which binds to the specific receptor type II (AMHR2) on the müllerian ducts, thus provoking their regression before the 10th week. In the absence of $\mathrm{AMH}$, the müllerian ducts form the fallopian tubes, the uterus, karger@karger.com www.karger.com/sxd (c) 2021 S. Karger AG, Basel

Karger
Correspondence to:

Rodolfo A. Rey, rodolforey@ cedie.org.ar 


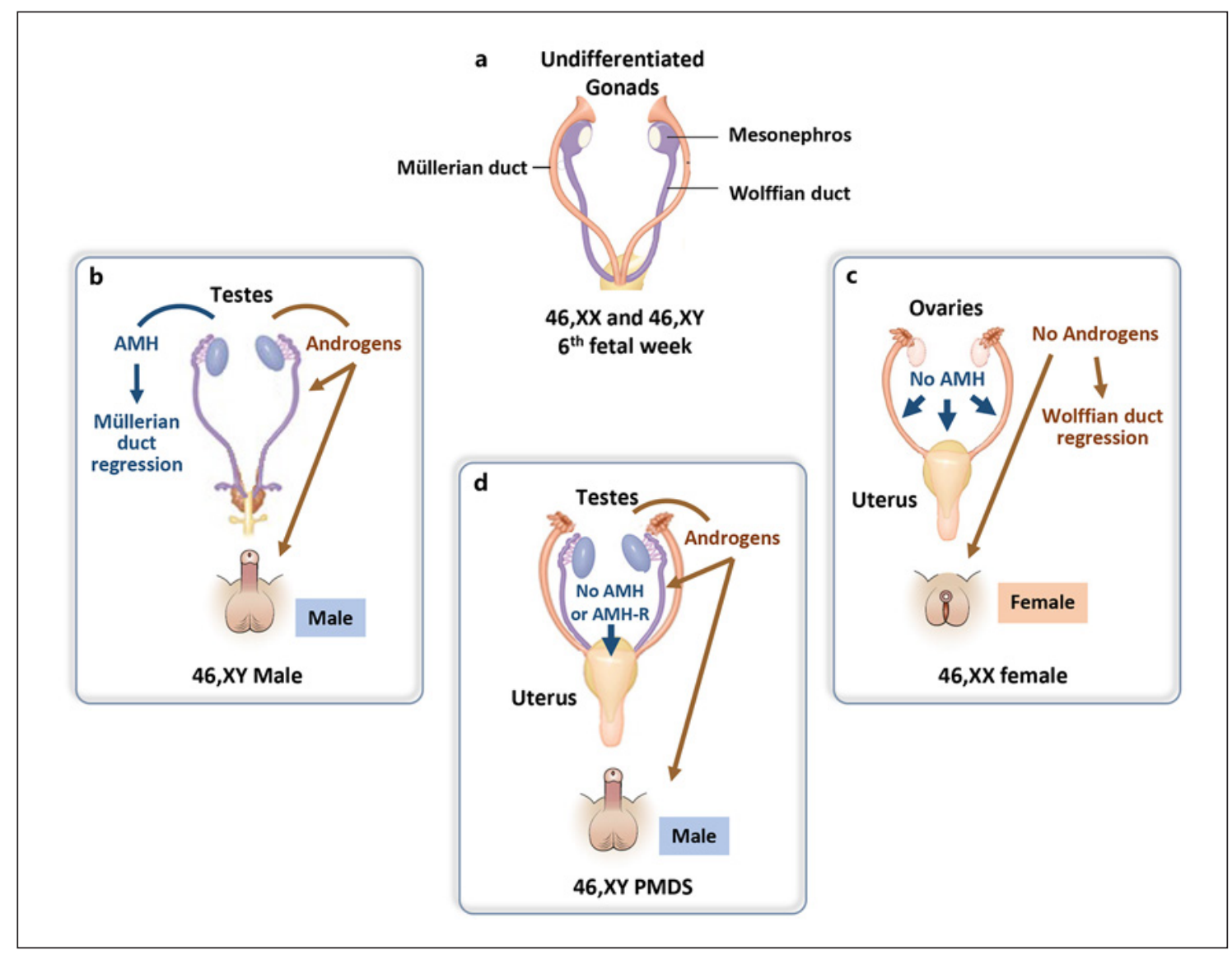

Fig. 1. Hormonal control of fetal sex differentiation. a In the human embryo, before the 7 th week, the primordia of the gonads and of the external genitalia are undifferentiated and sexually bipotential, while 2 duct systems coexist, the müllerian and the wolffian ducts, which are unipotential. $\mathbf{b}$ In the male, the testes secrete antimüllerian hormone (AMH), responsible for müllerian duct regression, and androgens, responsible for wolffian duct differentiation into the epididymis, vas deferens, and seminal vesicle, as well as for the virilization of the external genitalia. $\mathbf{c}$ In the female, the ovaries

and the upper part of the vagina. The second testicular hormone is testosterone, responsible for the differentiation of the wolffian ducts into the epididymides, the vasa deferentia, and the seminal vesicles, and the virilization of the external genitalia [Josso, 2019; Moses and Behringer, 2019; Grinspon et al., 2020].

\section{AMH and AMHR2 in Sex Development}

\section{AMH Production by the Gonads}

Because of its short and sexually dimorphic window of action in early fetal life, AMH production needs to be tightly regulated. In the testis, AMH expression is trig- do not secrete $\mathrm{AMH}$ or testosterone during the sex differentiation window, which leads the müllerian ducts to form the fallopian tubes, the uterus, and the upper portion of the vagina, the wolffian ducts to regress, and the external genitalia to feminize. $\mathbf{d}$ In $46, \mathrm{XY}$ individuals with mutations resulting in impaired expression of $\mathrm{AMH}$ or the $\mathrm{AMH}$ receptor type II, the müllerian duct derivatives develop, leading to the persistent müllerian duct syndrome (PMDS). Modified, with permission, from Josso and Rey [2020].

gered by SOX9 and upregulated by SF1, GATA4, and WT1, independently of gonadotropins [Valeri et al., 2020]. Later in fetal life and after birth, testicular AMH production is increased by the action of FSH [Al-Attar et al., 1997; Grinspon and Urrutia, 2020], signaling through its 7 transmembrane receptor and the pathway involving the Gsa subunit [Rey et al., 2006], cyclic AMP, protein kinase A, and transcription factors SOX9, SF1, AP2, and NFkB [Lukas-Croisier et al., 2003; Lasala et al., 2011]. Serum AMH is high during fetal life [Josso et al., 1993] and although it declines transiently at birth, it remains distinctly higher than in females and increases again during the first month [Bergadá et al., 2006] to reach its peak in the second year of life [Aksglæde et al., 2010; Grinspon et 
Fig. 2. Serum levels of $A M H$ in patients with persistent müllerian duct syndrome (PMDS) due to mutations in the $A M H$ or the AMHR2 gene or with no mutations detected. Data taken from Josso et al. [2005]. The shaded area represents reference levels for males, according to Grinspon et al. [2011].

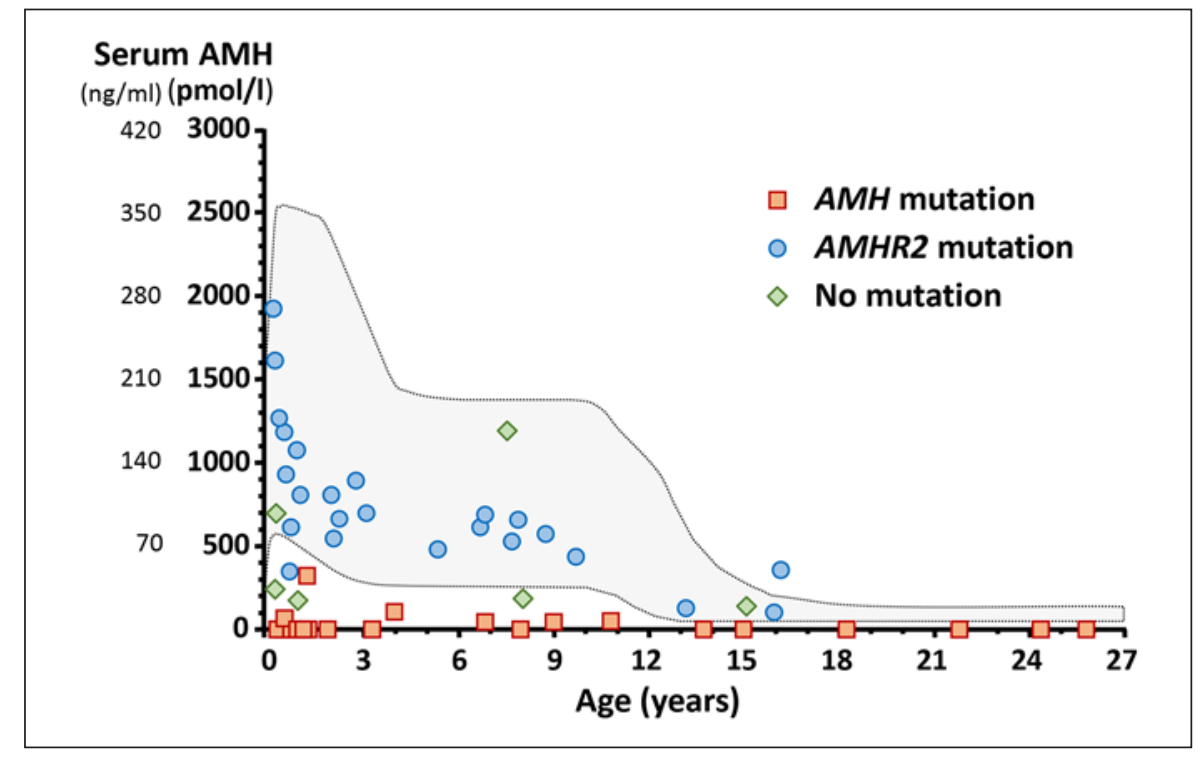

al., 2011]. Circulating levels remain high during childhood and decrease from the onset of puberty (Fig. 2) when $\mathrm{AMH}$ production is downregulated by the increasing intratesticular concentration of testosterone [Rey, 2021], which acts through the androgen receptor that hinders SF1 regulation at the AMH promoter [Edelsztein et al., 2018]. Interestingly, during the fetal period and early infancy, Sertoli cells are insensitive to the high levels of testosterone produced by the testis because they do not express the androgen receptor [Chemes et al., 2008; Boukari et al., 2009; Grinspon et al., 2013].

In the ovary, $\mathrm{AMH}$ is produced by the granulosa cells of primary and small antral follicles [Vigier et al., 1984; Rajpert-De Meyts et al., 1999; Rey et al., 2000], starting from the 25th week of fetal life [Kuiri-Hänninen et al., 2011], when müllerian ducts are already insensitive to AMH. Serum AMH is 50 -fold lower in girls than in boys at birth [Bergadá et al., 2006] and remains relatively stable from childhood through young adulthood [Long et al., 2000; Codner et al., 2007; Hagen et al., 2010; Kelsey et al., 2011], declining from the 4th decade until menopause, when it becomes undetectable as ovarian follicles are completely lost [Long et al., 2000; van Rooij et al., 2004; Kelsey et al., 2011; Nelson et al., 2011].

\section{AMH Action on Müllerian Ducts}

AMH signals through 2 distinct membrane-bound receptors. The AMH receptor type II (AMHR2) is a specific receptor to which $\mathrm{AMH}$ binds and triggers its action in the müllerian ducts, the most physiologically relevant target organ. The consequence of AMH action is ductal epithe- lial regression involving a paracrine mechanism initiated in the müllerian mesenchyme and consisting of apoptosis and epithelial-to-mesenchymal transition [Allard et al., 2000]. AMHR 2 recruits 1 of 2 non-specific type I receptors, either BMPR1A or ACVR1, thus inducing the phosphorylation of intracellular proteins SMAD1, SMAD5, and SMAD8 (also called SMAD9) and their translocation to the nucleus, where they regulate target gene expression [Josso, 2019; Moses and Behringer, 2019]. Osterix (OSX) is induced by $\mathrm{AMH}$ and involved in müllerian duct regression [Mullen et al., 2018]. $\beta$-catenin is required for AMH action [Kobayashi et al., 2011]. Matrix metallopeptidase 2 (MMP2) and WNT inhibitory factor 1 (WIF1) are 2 other factors that are expressed in the fetal male, but not the female, müllerian mesenchyme following $\mathrm{AMH}$ action [Roberts et al., 2002; Park et al., 2014].

Experimentally induced overexpression or disruption of the AMH pathway in mice provided the conclusive proof of the main role of the "müllerian inhibitor" suggested by Prof. Jost in his pioneering experiments in the mid-20th century [Jost, 1953]. Transgenic female mice overexpressing AMH lack a uterus and oviducts [Behringer et al., 1990]. Male mice with a homozygous knockout of the Amh gene [Behringer et al., 1994] or of SOX9- or SF1-response elements on the Amh promoter [Arango et al., 1999] have persistent müllerian derivatives but normal male wolffian duct derivatives and external genitalia and sperm production. Heterozygotes are phenotypically normal, corroborating the recessive mode of inheritance of the condition. Male mice with defective Amhr2 alleles show similar phenotypes [Mishina et al., 1996; Jamin et al., 2002; Arango et al., 2008]. 


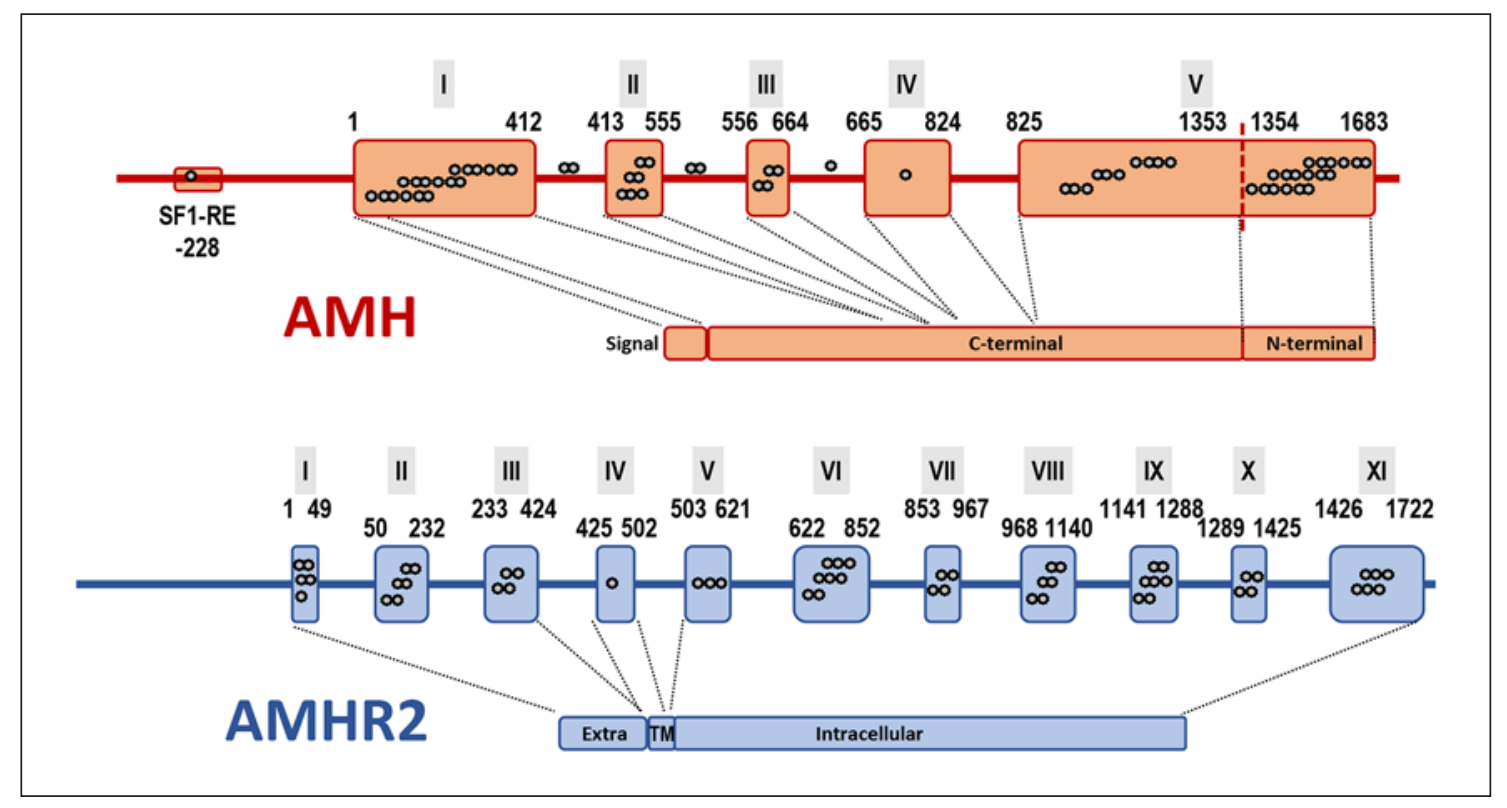

Fig. 3. Schematic of the $A M H$ and $A M H R 2$ genes and proteins. Roman numerals indicate exons, arabic numerals indicate initial and last base number of each exon. SF1-RE, SF1 response element at position -228 of the $A M H$ promoter; Extra, extracellular domain of AMHR2; TM, transmembrane domain of AMHR2. Dots indicate independent mutations described. Deletions are not included in this figure.

Other Sites of AMH Production and Action

AMH continues to be produced by the testis after müllerian duct regression, and the ovaries also secrete $\mathrm{AMH}$ when müllerian ducts are no longer sensitive. These observations suggest that AMH might have other physiological roles. In the testis, AMHR2 is expressed in Sertoli [Dutertre et al., 1997] and Leydig cells [Racine et al., 1998]. AMH overexpression inhibits Leydig cell differentiation and steroidogenesis, whereas deficiency of AMH action results in Leydig cell hyperplasia. In the ovary, AMH overexpression results in follicle disruption [Behringer et al., 1990]. Female mice with homozygous disruption of Amh or Amhr2 genes exhibit morphologically normal uteri and ovaries and are fertile, but primordial follicle recruitment rate is increased, resulting in early depletion [Durlinger et al., 1999]. AMH also inhibits aromatase, resulting in decreased estrogen production [di Clemente et al., 1992].

Using very sensitive experimental tools, $A M H$ and $A M H R 2$ expression have also been described in the brain [Lebeurrier et al., 2008; Wang et al., 2020], cerebellum [Wittmann and McLennan, 2011], and the hypothalamicpituitary axis [Cimino et al., 2016; Garrel et al., 2016]. The (patho)physiological relevance of these findings is incipient as compared to that related to $\mathrm{AMH}$ action on müllerian duct regression during fetal sex differentiation. In- deed, AMH cannot be detected in blood in the anorchid male [Lee et al., 1997] or in the castrated or menopausal female [Long et al., 2000], and no major phenotype apart from the existence of uterus and fallopian tubes has been described in patients with PMDS or in their female relatives with inactivating mutations of both alleles of $A M H$ or $A M H R 2$, as described in detail below. Subtle phenotypes might have gone underdiagnosed, and the reverse phenotyping approach derived from the use of massive parallel sequencing could help to shed light on this question.

\section{AMH and AMHR2: Genes and Proteins}

\section{$A M H$}

The human AMH gene (OMIM 600957) is autosomal, mapping to 19p13.3 (GRCh38: 2,249,309-2,252,073) [Cohen-Haguenauer et al., 1987], and consists of 5 exons and 4 introns spanning 2,764 bp (Fig. 3). Like for other members of the TGF $\beta$ superfamily, the $3^{\prime}$ end of the last exon encodes the bioactive C-terminal domain [Cate et al., 1986]. Unlike the bovine, rat, and mouse, the human $A M H$ promoter lacks a classical TATA-box and exhibits several transcription initiation sites. Response elements for SOX9, SF1, and GATA4 are present within the proximal 500 bp. 
Human AMH is synthesized as a $140-\mathrm{kD}$ glycoprotein homodimer, each monomer composed of 560 amino acids. Prior to secretion, a 24-amino acid signal peptide is removed. The full-length secreted pro-protein must be cleaved - most probably in target organs - at a site located 109 amino acids upstream from the C-terminus. The resulting $25 \mathrm{kD} \mathrm{C}$-terminal dimeric fragment is the bioactive moiety, whereas the $110-\mathrm{kD} \mathrm{N}$-terminal fragment enhances the bioactivity of the C-terminal domain [Wilson et al., 1993].

\section{AMHR2}

The human AMHR2 gene (OMIM 600956) is also autosomal and maps to 12q13.13 (GRCh38: 12:53,423,85453,431,671) [Imbeaud et al., 1995]. The gene consists of 11 exons (7,817 bp; Fig. 3): exon 1 encodes the signal sequence, exons 2 and 3 the extracellular domain with hormone binding capacity, exon 4 the single transmembrane domain, and exons 5-11 the intracellular domain involved in signal transduction. The AMH type II receptor is a 573 -amino acid protein of $82 \mathrm{kD}$ for the mature form. The $\mathrm{N}$-terminal extracellular domain binds $\mathrm{AMH}$ as the only ligand, whereas the intracellular domain has serine/ threonine kinase activity.

\section{AMH and AMHR2 Variants in Congenital Disorders \\ of the Reproductive Axis}

Disorders of sex development (DSD) are congenital conditions where chromosomal, gonadal, and/or genital sex are atypical or discordant. This definition includes sex chromosome disorders, that is, where an individual has an atypical sex chromosome complement such as $45, \mathrm{X} / 46, \mathrm{XY}, 46, \mathrm{XX} / 46, \mathrm{XY}$, etc., as well as $46, \mathrm{XX}$ individuals with more or less virilized genitalia and 46,XY individuals with female or ambiguous genitalia [Lee et al., 2006]. Defects in the AMH pathway represent a subgroup of 46,XY DSD characterized by the existence of internal female genitalia but normally differentiated male gonads [Grinspon et al., 2020].

\section{Persistence of Müllerian Duct Derivatives}

As expected, the first phenotype associated with defects in the AMH axis was the existence of a uterus and fallopian tubes in otherwise normally virilized 46,XY individuals. Since the initial description of a mutation in the AMH gene [Knebelmann et al., 1991], approximately 200 cases of patients with PMDS have been reported to date with molecular genetic characterization, the vast majority of them by the group led by Nathalie Josso and Jean-Yves Picard in Paris [Picard et al., 2017]. This condition is typ- ically characterized by the unexpected finding of a uterus and fallopian tubes in an otherwise normally virilized $46, \mathrm{XY}$ patient, generally seeking medical attention due to cryptorchidism. The clinical presentation may vary from bilateral cryptorchidism with testes located in an ovarian position, to unilateral cryptorchidism where the undescended testis is attached to tube and uterus and appears as an inguinal hernia (hernia uteri inguinalis), and to transverse testicular ectopia where both testes and part of the müllerian derivatives have herniated into a single side [Hutson et al., 2014]. More rarely, the clinical presentation is in adults with hemospermia, hematuria, or infertility. Any of these presentations may result from defective AMH production or to resistance to AMH due to AMHR2 impairment. Serum AMH is low or undetectable in the vast majority of $A M H$ gene mutations (Fig. 2) [Picard et al., 2017], except for a few cases where the resulting protein was immunologically detected by the $\mathrm{AMH}$ assays but functionally inactive [Belville et al., 2004]. In patients with AMHR2 defects, serum AMH is usually within the normal male range (Fig. 2) [Picard et al., 2017]. Malignant potential seems slightly increased as compared to males with cryptorchidism not associated with PMDS, which suggests that factors other than abnormal testicular position may play a role. Malignant degeneration of the müllerian derivatives is infrequent. Infertility is a frequent complication, usually associated with longstanding bilateral cryptorchidism or to involuntary damage of reproductive organ blood vessels during surgery [Picard et al., 2017].

In females, no evident phenotype has been reported. Sisters and mothers of boys with PMDS, carrying gene mutations in both alleles, are normal and fertile. Female mice with a knockout of the Amh gene show accelerated ovarian reserve depletion but with no apparent effect on lifetime fertility [Guo and Pankhurst, 2020].

\section{AMH Gene Variants}

A total of 72 different variants have been identified in 89 patients with PMDS; 64 of those variants are included in the exhaustive review by Picard and colleagues 4 years ago [Picard et al., 2017]. The remaining 8 have been reported in 7 patients thereafter (online suppl. Table 1; see www.karger.com/doi/10.1159/518273 for all online suppl. material). Variants are present either at homozygous or compound heterozygous states, that is, always consistent with an autosomal recessive pattern of inheritance. All types of variants have been reported, with missense mutations as the most frequent, in the 5 exons. Variants are extremely rare in exon 4 , whereas they are particu- 
larly frequent in exons 1 and 5 . Two variants in intron 1, 2 in intron 2, and 1 in intron 3 have been described [Picard et al., 2017]. Recently, the first variant in the 5 ' regulatory sequences of the $A M H$ gene was identified. The patient carried a single base deletion at 225 upstream of the translation start site, significantly decreasing its capacity for binding the transcription factor SF1 [Schteingart et al., 2019], which is essential for $A M H$ gene transcriptional activation [Shen et al., 1994].

With the advent of next-generation sequencing (NGS) technologies, 4 novel variants have been described [Hughes et al., 2019; Ata et al., 2021]. In all cases, the phenotype was typically that of PMDS and the mode of inheritance autosomal recessive. Consanguinity has been reported in approximately $40 \%$ of families with $A M H$ variants causing PMDS [Picard et al., 2017].

\section{AMHR2 Gene Variants}

In all, 78 variants have been reported to date in the AMHR2 gene in 95 patients with PMDS. Picard and colleagues [Picard et al., 2017] reviewed 58 of them, and the remaining 20, described in 15 patients, are shown in online suppl. Table 2. Like for the $A M H$ gene, variants are present in homozygous or compound heterozygous states. Although all types of variants have been described in exons 1-11 and in introns 2, 5, 7, and 8, a 27-bp deletion in exon 10, c.1332_1358del, has been reported in 32 families, representing by far the most frequent variant found in patients with PMDS. Recently, the first cases resulting from microdeletions of 12q13.13, where AMHR2 maps, were identified using high-resolution array CGH [Tosca et al., 2020]. In 1 case, a homozygous microdeletion of $11.39 \mathrm{~kb}$ removed exons 7-11 and extended beyond the AMHR2 gene, while in the second case, the whole AMHR2 gene was deleted. The recent use of NGS panels contributed to the detection of 11 variants ( 9 novel), present in homozygosity or compound heterozygosity, as expected for a condition transmitted as an autosomal recessive trait.

\section{Other Conditions Affecting the Reproductive Axis}

Interindividual Variability in the Normal Population

and Female Patients with Polycystic Ovary Syndrome

The increasing access to high throughput technologies has allowed the scrutiny of $A M H$ and $A M H R 2$ genes in patients with conditions different from PMDS. Circulating levels of $\mathrm{AMH}$ show high interindividual variability in the normal population [Aksglæde et al., 2010; Grinspon et al., 2011]. A recent genome-wide association study has identified common and low-frequency variants in the $A M H$ gene with strong association with circulating AMH levels in males [Perry et al., 2016]. In female patients with polycystic ovary syndrome (PCOS), serum $\mathrm{AMH}$ levels may also be very variable, and several $A M H$ and $A M H R 2$ variants have been shown to reduce $A M H$ expression or signaling capacity [Gorsic et al., 2019; Hoyos et al., 2020].

Pathogenic Association with Hypogonadotrophic Hypogonadism and Primary Ovarian Insufficiency

In a recent whole exome sequencing study of 136 patients with congenital hypogonadotrophic hypogonadism $(\mathrm{HH}), 3$ heterozygous missense variants were detected in the $A M H$ gene (online suppl. Table 1) and 1 heterozygous missense variant was found in the AMHR2 gene (online suppl. Table 2), all of them showing loss of function in in vitro experiments [Malone et al., 2019].

Another study of 120 female patients with primary ovarian insufficiency (POI) identified 14 variants of AMHR2, 10 of which were novel, and 2 were exonic missense variants (online suppl. Table 2) with potential impact on protein expression or function as predicted by bioinformatic tools [Qin et al., 2014].

In both conditions, the variants were found in only 1 allele at variance with those found in patients with PMDS, in whom both alleles are mutated. Whether these single allele variants may have a pathogenic role through a dominant mechanism needs to be clarified. The fact that a large number of point mutations or even large deletions completely abolishing AMH expression or AMHR2 signaling observed in patients with PMDS do not result in $\mathrm{HH}$ or POI argue against a major role of mutations in the $\mathrm{AMH}$ signaling pathway in the etiology of these conditions. However, a shared role with other pathways may be envisaged in conditions showing an oligogenic mode of transmission.

\section{Conclusion}

The AMH pathway is clearly involved in the regression of müllerian ducts in the male fetus, whereas other roles might be redundant or less determinant. Deleterious variants in $A M H$ or $A M H R 2$ result in the persistence of müllerian ducts and their differentiation into the uterus and fallopian tubes in 46,XY patients, who do not have any other sign of defective virilization. The advent of high throughput technologies, such as next-generation sequencing leading to a reverse phenotyping approach, 
may help to understand other potential roles for $\mathrm{AMH}$ and its signaling pathway by unveiling gene variants in unsuspected conditions.

\section{Conflict of Interest Statement}

R.A.R. has received royalties derived from an agreement between INSERM (France) and Beckman-Coulter-Immunotech for the development of an AMH ELISA kit, honoraria from CONICET (Argentina) for technology services using the AMH ELISA, lecture honoraria from Novo Nordisk and Sandoz, and travel grants from Biosidus, Merck, Novo Nordisk, Pfizer, and Sandoz.

\section{Funding Sources}

F.G.B. is recipient of a doctoral fellowship from CONICET (Argentina). This funding source had no role in the preparation of the manuscript.

\section{Author Contributions}

R.A.R. conceived the manuscript outline. F.G.B. and R.A.R. performed the data and bibliographic search, discussed the contents, contributed to the manuscript writing, and approved the final version.

\section{References}

Aksglæde L, Sorensen K, Boas M, Mouritsen A, Hagen $\mathrm{CP}$, Jensen RB, et al. Changes in anti-Müllerian hormone $(\mathrm{AMH})$ throughout the life span: a population-based study of 1027 healthy males from birth (cord blood) to the age of 69 years. J Clin Endocrinol Metab. 2010;95:5357-64.

Al-Attar L, Noël K, Dutertre M, Belville C, Forest MG, Burgoyne PS, et al. Hormonal and cellular regulation of Sertoli cell anti-Müllerian hormone production in the postnatal mouse. J Clin Invest. 1997;100:1335-43.

Allard S, Adin P, Gouédard L, di Clemente N, Josso $\mathrm{N}$, Orgebin-Crist MC, et al. Molecular mechanisms of hormone-mediated Müllerian duct regression: involvement of betacatenin. Development. 2000;127:3349-60.

Arango NA, Lovell-Badge R, Behringer RR. Targeted mutagenesis of the endogenous mouse Mis gene promoter: in vivo definition of genetic pathways of vertebrate sexual development. Cell. 1999;99:409-19.

Arango NA, Kobayashi A, Wang Y, Jamin SP, Lee $\mathrm{HH}$, Orvis GD, et al. A mesenchymal perspective of Müllerian duct differentiation and regression in Amhr2-lacZ mice. Mol Reprod Dev. 2008;75:1154-62.

Ata A, Özen S, Onay H, Uzun S, Gökșen D, Özkınay F, et al. A large cohort of disorders of sex development and their genetic characteristics: 6 novel mutations in known genes. Eur J Med Genet. 2021;64(3):104154.

Behringer RR, Cate RL, Froelick GJ, Palmiter RD, Brinster RL. Abnormal sexual development in transgenic mice chronically expressing müllerian inhibiting substance. Nature. 1990;345: $167-70$.

Behringer RR, Finegold MJ, Cate RL. Müllerianinhibiting substance function during mammalian sexual development. Cell. 1994;79:415-25.

Belville C, Van Vlijmen H, Ehrenfels C, Pepinsky B, Rezaie AR, Picard JY, et al. Mutations of the anti-mullerian hormone gene in patients with persistent mullerian duct syndrome: biosynthesis, secretion, and processing of the abnormal proteins and analysis using a three-dimensional model. Mol Endocrinol. 2004;18: $708-21$.
Bergadá I, Milani C, Bedecarrás P, Andreone L, Ropelato MG, Gottlieb S, et al. Time course of the serum gonadotropin surge, inhibins, and anti-Müllerian hormone in normal newborn males during the first month of life. J Clin Endocrinol Metab. 2006;91:4092-8.

Boukari K, Meduri G, Brailly-Tabard S, Guibourdenche J, Ciampi ML, Massin N, et al. Lack of androgen receptor expression in Sertoli cells accounts for the absence of anti-Müllerian hormone repression during early human testis development. J Clin Endocrinol Metab. 2009;94:1818-25.

Cate RL, Mattaliano RJ, Hession C, Tizard R, Farber NM, Cheung A, et al. Isolation of the bovine and human genes for Müllerian inhibiting substance and expression of the human gene in animal cells. Cell. 1986;45:685-98.

Chemes HE, Rey RA, Nistal M, Regadera J, Musse M, González-Peramato P, et al. Physiological androgen insensitivity of the fetal, neonatal, and early infantile testis is explained by the ontogeny of the androgen receptor expression in Sertoli cells. J Clin Endocrinol Metab. 2008;93:4408-12.

Cimino I, Casoni F, Liu X, Messina A, Parkash J, Jamin SP, et al. Novel role for anti-Müllerian hormone in the regulation of GnRH neuron excitability and hormone secretion. Nat Commun. 2016;7:10055.

Codner E, Iñíguez G, Villarroel C, Lopez P, Soto N, Sir-Petermann T, et al. Hormonal profile in women with polycystic ovarian syndrome with or without type 1 diabetes mellitus. J Clin Endocrinol Metab. 2007;92:4742-6.

Cohen-Haguenauer O, Picard JY, Mattéi MG, Serero S, Nguyen VC, de Tand MF, et al. Mapping of the gene for anti-Müllerian hormone to the short arm of human chromosome 19. Cytogenet Cell Genet. 1987;44:2-6.

di Clemente N, Ghaffari S, Pepinsky RB, Pieau C, Josso N, Cate RL, et al. A quantitative and interspecific test for biological activity of antiMüllerian hormone: the fetal ovary aromatase assay. Development. 1992;114:721-7.

Durlinger AL, Kramer P, Karels B, de Jong FH, Uilenbroek JT, Grootegoed JA, et al. Control of primordial follicle recruitment by antiMüllerian hormone in the mouse ovary. Endocrinology. 1999;140:5789-96.

Dutertre M, Rey R, Porteu A, Josso N, Picard JY. A mouse Sertoli cell line expressing anti-Müllerian hormone and its type II receptor. Mol Cell Endocrinol. 1997;136:57-65.

Edelsztein NY, Racine C, di Clemente N, Schteingart HF, Rey RA. Androgens downregulate anti-Müllerian hormone promoter activity in the Sertoli cell through the androgen receptor and intact steroidogenic factor 1 sites. Biol Reprod. 2018;99:1303-12.

Garrel G, Racine C, L'Hote D, Denoyelle C, Guigon CJ, di Clemente N, et al. Anti-Müllerian hormone: a new actor of sexual dimorphism in pituitary gonadotrope activity before puberty. Sci Rep. 2016;6:23790.

Gorsic LK, Dapas M, Legro RS, Hayes MG, Urbanek M. Functional genetic variation in the anti-Müllerian hormone pathway in women with polycystic ovary syndrome. J Clin Endocrinol Metab. 2019;104:2855-74.

Grinspon RP, Urrutia M. The importance of follicle-stimulating hormone in the prepubertal and pubertal testis. Curr Opin Endocr Metab Res. 2020;14:137-44.

Grinspon RP, Bedecarrás P, Ballerini MG, Iñiguez G, Rocha A, Mantovani Rodrigues Resende EA, et al. Early onset of primary hypogonadism revealed by serum anti-Müllerian hormone determination during infancy and childhood in trisomy 21. Int J Androl. 2011; 34:e487-98.

Grinspon RP, Andreone L, Bedecarrás P, Ropelato MG, Rey RA, Campo SM, et al. Male central precocious puberty: serum profile of antiMüllerian hormone and inhibin B before, during, and after treatment with GnRH analogue. Int J Endocrinol. 2013;2013:823064.

Grinspon RP, Bergadá I, Rey RA. Male hypogonadism and disorders of sex development. Front Endocrinol (Lausanne). 2020;11:211.

Guo R, Pankhurst MW. Accelerated ovarian reserve depletion in female anti-Müllerian hormone knockout mice has no effect on lifetime fertility†. Biol Reprod. 2020;102:915-22. 
Hagen CP, Aksglaede L, Sørensen K, Main KM, Boas M, Cleemann L, et al. Serum levels of anti-Müllerian hormone as a marker of ovarian function in 926 healthy females from birth to adulthood and in 172 Turner syndrome patients. J Clin Endocrinol Metab. 2010;95: 5003-10.

Hoyos LR, Visser JA, McLuskey A, Chazenbalk GD, Grogan TR, Dumesic DA. Loss of antiMüllerian hormone (AMH) immunoactivity due to a homozygous AMH gene variant rs10417628 in a woman with classical polycystic ovary syndrome (PCOS). Hum Reprod. 2020;35:2294-302.

Hughes LA, McKay-Bounford K, Webb EA, Dasani P, Clokie S, Chandran H, et al. Next generation sequencing (NGS) to improve the diagnosis and management of patients with disorders of sex development (DSD). Endocr Connect. 2019;8:100-10.

Hutson JM, Grover SR, O'Connell M, Pennell SD. Malformation syndromes associated with disorders of sex development. Nat Rev Endocrinol. 2014;10:476-87.

Imbeaud S, Faure E, Lamarre I, Mattéi MG, di Clemente N, Tizard R, et al. Insensitivity to anti-Müllerian hormone due to a mutation in the human anti-Müllerian hormone receptor. Nat Genet. 1995;11:382-8.

Jamin SP, Arango NA, Mishina Y, Hanks MC, Behringer RR. Requirement of Bmprla for Müllerian duct regression during male sexual development. Nat Genet. 2002;32:408-10.

Josso N. WOMEN IN REPRODUCTIVE SCIENCE: Anti-Müllerian hormone: a look back and ahead. Reproduction. 2019;158:F81F89.

Josso N, Rey RA. What does AMH tell us in pediatric disorders of sex development? Front Endocrinol (Lausanne). 2020;11:619.

Josso N, Lamarre I, Picard JY, Berta P, Davies N, Morichon N, et al. Anti-Müllerian hormone in early human development. Early Hum Dev. 1993;33:91-9.

Josso N, Belville C, di Clemente N, Picard JY. $\mathrm{AMH}$ and $\mathrm{AMH}$ receptor defects in persistent Müllerian duct syndrome. Hum Reprod Update. 2005;11:351-6.

Jost A. Problems of fetal endocrinology: the gonadal and hypophyseal hormones. Recent Prog Horm Res. 1953;8:379-418.

Kelsey TW, Wright P, Nelson SM, Anderson RA, Wallace WH. A validated model of serum anti-müllerian hormone from conception to menopause. PLoS One. 2011;6: e22024.

Knebelmann B, Boussin L, Guerrier D, Legeai L, Kahn A, Josso N, et al. Anti-Müllerian hormone Bruxelles: a nonsense mutation associated with the persistent Müllerian duct syndrome. Proc Natl Acad Sci USA. 1991;88: 3767-71.

Kobayashi A, Stewart CA, Wang Y, Fujioka K, Thomas NC, Jamin SP, et al. $\beta$-Catenin is essential for Müllerian duct regression during male sexual differentiation. Development. 2011;138:1967-75.
Kuiri-Hänninen T, Kallio S, Seuri R, Tyrväinen E, Liakka A, Tapanainen J, et al. Postnatal developmental changes in the pituitary-ovarian axis in preterm and term infant girls. J Clin Endocrinol Metab. 2011;96:3432-9.

Lasala C, Schteingart HF, Arouche N, Bedecarrás P, Grinspon RP, Picard JY, et al. SOX9 and $\mathrm{SF} 1$ are involved in cyclic AMP-mediated upregulation of anti-Mullerian gene expression in the testicular prepubertal Sertoli cell line SMAT1. Am J Physiol Endocrinol Metab. 2011;301:E539-47.

Lebeurrier N, Launay S, Macrez R, Maubert E, Legros H, Leclerc A, et al. Anti-Mullerianhormone-dependent regulation of the brain serine-protease inhibitor neuroserpin. J Cell Sci. 2008;121:3357-65.

Lee MM, Donahoe PK, Silverman BL, Hasegawa T, Hasegawa Y, Gustafson ML, et al. Measurements of serum Müllerian inhibiting substance in the evaluation of children with nonpalpable gonads. N Engl J Med. 1997;336: $1480-6$.

Lee PA, Houk CP, Ahmed SF, Hughes IA,International Consensus Conference on Intersex organized by the Lawson Wilkins Pediatric Endocrine Society and the European Society for Paediatric Endocrinology. Consensus Statement on Management of Intersex Disorders. Pediatrics. 2006;118:e488e500.

Long WQ, Ranchin V, Pautier P, Belville C, Denizot P, Cailla H, et al. Detection of minimal levels of serum anti-Müllerian hormone during follow-up of patients with ovarian granulosa cell tumor by means of a highly sensitive enzyme-linked immunosorbent assay. J Clin Endocrinol Metab. 2000; 85:540-4.

Lukas-Croisier C, Lasala C, Nicaud J, Bedecarrás P, Kumar TR, Dutertre M, et al. Folliclestimulating hormone increases testicular anti-Müllerian hormone (AMH) production through Sertoli cell proliferation and a nonclassical cyclic adenosine 5'-monophosphate-mediated activation of the AMH gene. Mol Endocrinol. 2003;17:55061.

Malone SA, Papadakis GE, Messina A, Mimouni NEH, Trova S, Imbernon M, et al. Defective AMH signaling disrupts GnRH neuron development and function and contributes to hypogonadotropic hypogonadism. Elife. 2019;8: e47198.

Mishina Y, Rey R, Finegold MJ, Matzuk MM, Josso N, Cate RL, et al. Genetic analysis of the Müllerian-inhibiting substance signal transduction pathway in mammalian sexual differentiation. Genes Dev. 1996;10:2577-87.

Moses MM, Behringer RR. A gene regulatory network for Müllerian duct regression. Environ Epigenet. 2019;5:dvz017.

Mullen RD, Wang Y, Liu B, Moore EL, Behringer RR. Osterix functions downstream of antiMüllerian hormone signaling to regulate Müllerian duct regression. Proc Natl Acad Sci USA. 2018;115:8382-7.
Nelson SM, Messow MC, McConnachie A, Wallace H, Kelsey T, Fleming R, et al. External validation of nomogram for the decline in serum anti-Mullerian hormone in women: a population study of 15,834 infertility patients. Reprod Biomed Online. 2011;23:2046.

Park JH, Tanaka Y, Arango NA, Zhang L, Benedict LA, Roh MI, et al. Induction of WNT inhibitory factor 1 expression by Müllerian inhibiting substance/antiMüllerian hormone in the Müllerian duct mesenchyme is linked to Müllerian duct regression. Dev Biol. 2014; 386(1):227-36

Perry JR, McMahon G, Day FR, Ring SM, Nelson SM, Lawlor DA. Genome-wide association study identifies common and low-frequency variants at the $\mathrm{AMH}$ gene locus that strongly predict serum AMH levels in males. Hum Mol Genet. 2016;25:382-8.

Picard JY, Cate RL, Racine C, Josso N. The persistent Müllerian duct syndrome: An update based upon a personal experience of 157 cases. Sex Dev. 2017;11:109-25.

Qin C, Yuan Z, Yao J, Zhu W, Wu W, Xie J. AMH and AMHR2 genetic variants in Chinese women with primary ovarian insufficiency and normal age at natural menopause. Reprod Biomed Online. 2014;29:311-8.

Racine C, Rey R, Forest MG, Louis F, Ferré A, Huhtaniemi I, et al. Receptors for anti-Müllerian hormone on Leydig cells are responsible for its effects on steroidogenesis and cell differentiation. Proc Natl Acad Sci USA. 1998; 95:594-9.

Rajpert-De Meyts E, Jørgensen N, Græm N, Müller J, Cate RL, Skakkebæk NE. Expression of anti-Müllerian hormone during normal and pathological gonadal development: association with differentiation of Sertoli and granulosa cells. J Clin Endocrinol Metab. 1999;84: 3836-44.

Rey RA. The role of androgen signaling in male sexual development at puberty. Endocrinology. 2021;162(2).

Rey R, Sabourin JC, Venara M, Long WQ, Jaubert F, Zeller WP, et al. Anti-Müllerian hormone is a specific marker of Sertoli- and granulosacell origin in gonadal tumors. Hum Pathol. 2000;31:1202-8.

Rey RA, Venara M, Coutant R, Trabut JB, Rouleau S, Lahlou $\mathrm{N}$, et al. Unexpected mosaicism of R201H-GNAS1 mutant-bearing cells in the testes underlie macro-orchidism without sexual precocity in McCune-Albright syndrome. Hum Mol Genet. 2006;15: 3538-43.

Roberts LM, Visser JA, Ingraham HA. Involvement of a matrix metalloproteinase in MISinduced cell death during urogenital development. Development. 2002;129:1487-96.

Schteingart HF, Picard JY, Valeri C, Marshall I, Treton D, di Clemente N, et al. A mutation inactivating the distal SF1 binding site on the human anti-Müllerian hormone promoter causes persistent Müllerian duct syndrome. Hum Mol Genet. 2019;28:3211-8. 
Shen WH, Moore CC, Ikeda Y, Parker KL, Ingraham HA. Nuclear receptor steroidogenic factor 1 regulates the Müllerian inhibiting substance gene: a link to the sex determination cascade. Cell. 1994;77:651-61.

Tosca L, Giltay JC, Bouvattier C, Klijn AJ, Bouligand J, Lambert AS, et al. Persistent Müllerian duct syndrome due to anti-Müllerian hormone receptor 2 microdeletions: a diagnostic challenge. Hum Reprod. 2020;35:999-1003.

Valeri C, Lovaisa MM, Racine C, Edelsztein NY, Riggio M, Giulianelli S, et al. Molecular mechanisms underlying AMH elevation in hyperoestrogenic states in males. Sci Rep. 2020;10: 15062. van Rooij IA, Tonkelaar I, Broekmans FJ, Looman CW, Scheffer GJ, de Jong FH, et al. Anti-Müllerian hormone is a promising predictor for the occurrence of the menopausal transition. Menopause. 2004;11:601-6.

Vigier B, Picard JY, Tran D, Legeai L, Josso N. Production of anti-Müllerian hormone: another homology between Sertoli and granulosa cells. Endocrinology. 1984;114:131520.

Wang K, Xu F, Campbell SP, Hart KD, Durham T, Maylie J, et al. Rapid actions of anti-Müllerian hormone in regulating synaptic transmission and long-term synaptic plasticity in the hippocampus. FASEB J. 2020;34:706-19.
Wilson CA, di Clemente N, Ehrenfels C, Pepinsky RB, Josso N, Vigier B, et al. Mullerian inhibiting substance requires its $\mathrm{N}$-terminal domain for maintenance of biological activity, a novel finding within the transforming growth factor-beta superfamily. Mol Endocrinol. 1993; 7:247-57.

Wittmann W, McLennan IS. The male bias in the number of Purkinje cells and the size of the murine cerebellum may require Müllerian inhibiting substance/anti-Müllerian hormone. J Neuroendocrinol. 2011;23:831-8. 